\title{
Forest continuity and conservation value in Western Europe
}

\begin{tabular}{|c|c|}
\hline Journal: & The Holocene \\
\hline Manuscript ID: & HOL-14-0044.R1 \\
\hline Manuscript Type: & Paper \\
\hline Date Submitted by the Author: & 08-Jul-2014 \\
\hline Complete List of Authors: & $\begin{array}{l}\text { Bradshaw, Richard; Liverpool University, } \\
\text { Jones, Claire; Edge Hill University, Department of Geography } \\
\text { Edwards, Sarah; University of Leeds, Geography } \\
\text { Hannon, Gina; University of Liverpool, Geography }\end{array}$ \\
\hline Keywords: & $\begin{array}{l}\text { forest continuity, conservation value, Atlantic oakwoods, primary forest, } \\
\text { late Holocene, ancient woodland, forest continuity, pollen analysis, small } \\
\text { forest hollow, Western Europe }\end{array}$ \\
\hline Abstract: & $\begin{array}{l}\text { Long forest continuity has often been linked with high conservation value in } \\
\text { western European Quercus and Fagus woodlands, but this assumption of } \\
\text { long continuity has rarely been tested. Birks (1993) discussed the antiquity } \\
\text { of bryophyte-rich Quercus woodland in western United Kingdom presenting } \\
\text { evidence that the modern plant communities developed during the late } \\
\text { Holocene influenced by human activities. We use pollen data from forest } \\
\text { hollows to show that the modern communities within ancient woodlands } \\
\text { are all significantly influenced by recent human disturbance. A short period } \\
\text { of deforestation in Johnny's Wood, Cumbria, UK dates from the late } \\
\text { nineteenth century and is not of Viking age as previously thought. The brief } \\
\text { opening of the forest is associated with the local loss of Tilia cordata and } \\
\text { Taxus baccata, but a rich bryophyte community exists today. Rich lichen } \\
\text { floras of high conservation interest growing on Fagus sylvatica in south- } \\
\text { western Sweden occur despite a recent history of human disturbance and } \\
\text { local immigration of Fagus as recently as the ninth century AD. Wistman's } \\
\text { Wood, Cornwall, UK had a diverse tree flora until the eleventh century AD } \\
\text { and then experienced heavy browsing and grazing until AD } 1850 \text {, after } \\
\text { which time the present Quercus woodland developed with its associated } \\
\text { flora of high conservation value. Most western European forests today have } \\
\text { long and diverse histories of anthropogenic disturbance and current } \\
\text { conservation values incorporate both natural and cultural features. Pollen } \\
\text { studies with high spatial resolution demonstrate that simple temporal } \\
\text { concepts like 'natural baselines' and the continuity of forest cover } \\
\text { underestimate the complexity of the past. Long forest continuity may be of } \\
\text { importance for the local survival of higher plants, but for the insects, fungi, } \\
\text { lichens and bryophytes that are so valued in contemporary European } \\
\text { temperate and boreal forests, habitat diversity maintained by dynamic } \\
\text { processes would appear to be of greater significance. }\end{array}$ \\
\hline
\end{tabular}


Note: The following files were submitted by the author for peer review, but cannot be converted to PDF. You must view these files (e.g. movies) online.

Fig.3.emf

\section{SCHOLARONE" \\ Manuscripts}

13

14

15

16

17

18

19

20

21

22

23

24

25

26

27

28

29

30

31

32

33

34

35

36

37

38

39

40

41

42

43

44

45

46

47

48

49

50

51

52

53

54

55

56

57

58

59

60 


\title{
Forest continuity and conservation value in Western Europe
}

\begin{abstract}
Long forest continuity has often been linked with high conservation value in western European Quercus and Fagus woodlands, but this assumption of long continuity has rarely been tested. Birks (1993) discussed the antiquity of bryophyte-rich Quercus woodland in western United Kingdom presenting evidence that the modern plant communities developed during the late Holocene influenced by human activities. We use pollen data from forest hollows to show that the modern communities within ancient woodlands are all significantly influenced by recent human disturbance. A short period of deforestation in Johnny's Wood, Cumbria, UK dates from the late nineteenth century and is not of Viking age as previously thought. The brief opening of the forest is associated with the local loss of Tilia cordata and Taxus baccata, but a rich bryophyte community exists today. Rich lichen floras of high conservation interest growing on Fagus sylvatica in south-western Sweden occur despite a recent history of human disturbance and local immigration of Fagus as recently as the ninth century AD. Wistman's Wood, Cornwall, UK had a diverse tree flora until the eleventh century $A D$ and then experienced heavy browsing and grazing until $A D 1850$, after which time the present Quercus woodland developed with its associated flora of high conservation value. Most western European forests today have long and diverse histories of anthropogenic disturbance and current conservation values incorporate both natural and cultural features. Pollen studies with high spatial resolution demonstrate that simple temporal concepts like 'natural baselines' and the continuity of forest cover underestimate the complexity of the past. Long forest continuity may be of importance for the local survival of higher plants, but for the insects, fungi, lichens and bryophytes that are so valued in contemporary European temperate and boreal forests, habitat diversity maintained by dynamic processes would appear to be of greater significance.
\end{abstract}




\section{Introduction}

There are a number of long-term states and processes that are relevant for conservation biology, including biodiversity baselines, thresholds and resilience to climate change (Willis, Bailey et al. 2010). The concepts of primary and secondary forest are widely used to guide conservation policy, particularly in tropical regions, where there are often marked differences in structure and composition between primary and secondary forest (Waltert, Bobo et al. 2011). Criteria for distinguishing primary from secondary forest in tropical areas are rarely discussed as recent clearance episodes are often easily identified in the field. However if previous forest clearance is further back in time, it can be harder to detect and the effects of clearance may therefore be effectively reversible (Willis, Gillson et al. 2004). Segerström et al. (1994) found that a northern Swedish boreal forest that had been cleared by human activities between AD 1500-1700, was today indistinguishable in overall species content from unmanaged primary forest. By contrast, Dambrine et al. (2007) found a significant legacy in the ground flora from a 2000 year old clearance of temperate forest in northern France.

The Convention on Biological Diversity (CBD) has defined primary and secondary forest, but allows for considerable flexibility in its primary forest definition in Europe and acknowledges potential overlap with secondary forest where there have been longer periods of human activity (Table 1). As Willis et al. (2004) suggested, this complexity may well apply to other regions of the world where less is known about long-term vegetation history. Studies of the biodiversity of primary and secondary forests are often based on field plots of around 0.25 ha (Waltert, Bobo et al. 2011) and observations at this spatial scale can be hard to relate to regional vegetational histories reconstructed from pollen analysis of lakes and larger peatlands because conventional pollen analysis records vegetational change at spatial and temporal scales that are largely unfamiliar to the plant ecologist (Bradshaw 2013). Forest hollows and other 'closed-canopy' sites, by contrast, are 
dominated by pollen and spores that have only travelled a short distance from source plants and thus resolve vegetation dynamics at the scale of the woodland stand. Vegetation can be reconstructed with very high spatial resolution at a comparable spatial scale to typical plot-based surveys of modern vegetation. Thus, stand-scale palynology provides a key link between palaeoecological and contemporary ecological and conservation studies and can help assess the successional status of forested areas (Bradshaw 2013; Lindbladh, Fraver et al. 2013). In this paper we use records from small forest hollows in Western Europe to examine the relationship between past human impact and current conservation value at three forest sites with high biodiversity.

Birks (1993), in one of the first forest hollow studies in the British Isles, showed that a forest currently dominated by Quercus robur in north-western Britain that contained an "internationally important assemblage of Atlantic bryophytes has no long history and appears to have developed comparatively recently as a result of changes in land-use and woodland management." This statement was based on his own study in north-western Britain and earlier research of Edwards (1986) in Wales and Mitchell $(1988 ; 1990)$ in Ireland. Birks (1993) further commented that "the rather scanty data from such local-scale pollen studies on the history of specific plant communities at the association level indicate that many, if not all, have originated in the late Holocene, usually closely associated with human activity and land-use change. It appears that modern plant associations in Europe cannot usually be traced for more than $1000-1500$ years at the most. Many appear to have arisen by the direct or indirect influence of humans and their animals." These statements have rarely been rigorously tested within conservation biology, although forest cover for at least the last thousand years is included in the CBD primary forest definition (Table 1) and our understanding of the relationship between ancient and primary European woodlands has developed through time (Goldberg, Kirby et al. 2007). It is timely to test hypotheses about the conservation value of long forest continuity against more of the data that have appeared from forest hollows since 1993 (Willis and Birks 2006; Birks 2012; Mitchell 2013) and here we present three forest hollow sites from the British Isles and Sweden. All the sites are protected nature reserves today and part of 
their natural values have been presumed to be linked with long forest continuity. We use these palaeoecological records to test the hypothesis that perceived forest conservation value is directly linked to long-term forest cover and the primary forest condition.

Table 1. Definitions of primary and secondary forest (https://www.cbd.int/forest/definitions.shtml)

\begin{tabular}{|l|l|}
\hline Primary forest & $\begin{array}{l}\text { A primary forest is a forest that has never been logged and has developed following } \\
\text { natural disturbances and under natural processes, regardless of its age. It is referred to } \\
\text { "direct human disturbance" as the intentional clearing of forest by any means (including } \\
\text { fire) to manage or alter them for human use. Also included as primary, are forests that } \\
\text { are used inconsequentially by indigenous and local communities living traditional } \\
\text { lifestyles relevant for the conservation and sustainable use of biological diversity. In } \\
\text { much of Europe, primary forest has a different connotation and refers to an area of forest } \\
\text { land which has probably been continuously wooded at least throughout historical times } \\
\text { (e.g., the last thousand years). It has not been completely cleared or converted to } \\
\text { another land use for any period of time. However traditional human disturbances such as } \\
\text { patch felling for shifting cultivation, coppicing, burning and also, more recently, } \\
\text { selective/partial logging may have occurred, as well as natural disturbances. The present } \\
\text { cover is normally relatively close to the natural composition and has arisen } \\
\text { (predominantly) through natural regeneration, but planted stands can also be found. } \\
\text { However, the suggested definition above would include other forests, such as secondary } \\
\text { forests }\end{array}$ \\
\hline Secondary forest & $\begin{array}{l}\text { A secondary forest is a forest that has been logged and has recovered naturally or } \\
\text { artificially. Not all secondary forests provide the same value to sustaining biological } \\
\text { diversity, or goods and services, as did primary forest in the same location. In Europe, } \\
\text { secondary forest is forest land where there has been a period of complete clearance by } \\
\text { humans with or without a period of conversion to another land use. Forest cover has } \\
\text { regenerated naturally or artificially through planting. }\end{array}$ \\
\hline
\end{tabular}

\section{Material and Methods}


Site descriptions and conservation value

Johnny's Wood $\left(54^{\circ} 31^{\prime} \mathrm{N}, 3^{\circ} 09^{\prime} \mathrm{W}\right)$ is situated towards the southern end of Borrowdale in the English Lake District. Occupying a wet forest area of $37 \mathrm{ha}$, it is a hanging type wood on steep slopes ranging from 100 to 270 m.a.s.I. and covering all aspects (Ratcliffe 1977). The underlying bedrock sequence consists almost entirely of the Borrowdale Volcanic series, which generally provides acidic soils. The small forest hollow is located within stands of Quercus petraea (sessile oak) woodland. A shrub layer is absent with merely scattered individuals of Betula pubescens (birch), Ilex aquifolium (holly) and Sorbus aucuparia (rowan). Atlantic Quercus petraea woodlands are identified as a habitat of high importance in the European Union Habitat Directive with upland Quercus petraea woods a priority habitat in the UK. The forest floor has one of the most diverse assemblages of the internationally important oceanic bryophytes in the United Kingdom. In total 136 bryophytes species have been identified including the rare British moss Samatophyllum micans. The site is of high conservation value and is designated both as a Special Area of Conservation and a Site of Special Scientific Interest.

Wistman's Wood $\left(50^{\circ} 35^{\prime} \mathrm{N}, 3^{\circ} 58^{\prime} \mathrm{W}\right)$ is a 3 ha Quercus robur (pedunculate oak) woodland situated on the lower west-facing slopes of the West Dart valley at an altitude of 380 to 435 m.a.s.I., Devon, UK. The woodland lies on Dartmoor which is a large granitic, upland complex of heathland, acid grassland and blanket peat. The woodland also contains Ilex aquifolium, Sorbus aucuparia and some Salix aurita (eared willow). The ground flora is characterised by Vaccinium myrtillus (bilberry), Holcus mollis (creeping soft grass), Luzula sylvatica (great woodrush) and Rubus fruiticosus (bramble). There are pockets of mor humus accumulation among the rocky clitter and one of these was sampled for pollen analysis. This National Nature Reserve is one of the most famous woodlands in the UK noted for its gnarled Quercus trees and luxuriant bryophyte and lichen flora growing on clitter. Altogether 47 species of mosses and liverworts and 119 species of lichen have been recorded here. One of the rarest lichens Bryoria smithii is found only on four Wistman trees and in nearby 
Black Tor Copse, but nowhere else in the UK. The site is assumed to have a long continuity of forest cover and be ancient woodland (Coppins and Coppins 2005).

Almeberget, Halland, Sweden $\left(56^{\circ} 51^{\prime} \mathrm{N}, 12^{\circ} 53^{\prime} \mathrm{E}\right)$ is a deciduous forest county nature reserve dominated by Fagus sylvatica (beech). The 70 ha area is on hilly terrain at an altitude of 85 to 150 m.a.s.l. The site cored is a wet marshland area in a long, continuous channel at the bottom of a valley within the reserve. It is fed by a running stream, a tributary of the lake at Sällstorp. The reserve is marked as forest on maps from the seventeenth century. The oldest trees are over 200 years of age and there is abundant dead wood. The lichen flora is particularly rich and includes 21 red-listed species, among which is the extremely rare Pertusaria velata. Fungi, bryophytes and insects are also well represented with a total of 38 red-listed species recorded from the reserve. Fritz et al. (2008) found that Almeberget and other Fagus forests in southern Sweden that had a continuity of over 350 years had significantly higher numbers of lichens and bryophytes than recently planted forests not marked on older maps.

\section{Palaeoecological methods}

The small forest hollow within Johnny's Wood is a small circular closed basin that measures c. 20$30 \mathrm{~m}$ in diameter and is the same site that was sampled and analysed by Birks (1993). A single peat

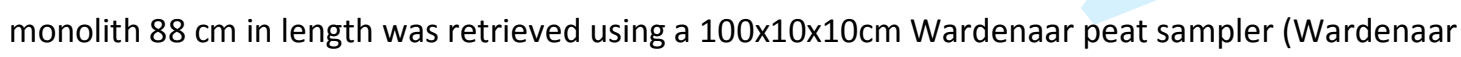
1987). The monolith was wrapped in plastic film and secured between wooden planks for transport and refrigerated storage. $37.5 \mathrm{~cm}$ of mor humus was collected from a site between granitic boulders in the centre of Wistman's Wood. Two half drain pipes were pushed into the humus, taped together and excavated. The core was wrapped in plastic film and stored in a freezer. A $1 \mathrm{~m}$ core was collected from the hollow at Almeberget using an $8 \mathrm{~cm}$ diameter Russian corer. The core was wrapped in plastic for transport and sliced into $1 \mathrm{~cm}$ segments and frozen prior to pollen and 
charcoal analysis. Charcoal analysis for Almeberget was based on particles larger than 250 microns following the photographic method of Mooney and Black (2003). Small forest hollows have been demonstrated in theory (Prentice 1985) and practice (Sugita, Parshall et al. 2010) to sample the majority of pollen from within 100-1000 m. This represents a spatial scale similar to the scales at which practical conservation often takes place, such as reserve selection and management (Lindbladh, Niklasson et al. 2008). Preparation of the samples for pollen analyses followed standard methods (Berglund 1986; Moore, Webb et al. 1991) and counts were made at $\times 400$ magnification with some finds checked at $\times 1000$ magnification. Pollen percentages were expressed as the sum of terrestrial pollen and spores excluding Sphagnum and aquatics, although these were counted.

Total concentrations of atmospherically deposited lead $(\mathrm{Pb})$ were determined for the Johnny's Wood and Almeberget sediment. A total of 20 samples were taken at $4 \mathrm{~cm}$ intervals, freeze dried, and then using an agate mortar, ground to form a powder. The powder was pressed into standard holders and analysed using S2 Ranger X-ray Fluorescence Spectrometry (XRF) spectrometer (University of Liverpool). Calibrations were made using standard reference material.

\section{Dating}

Four chronological markers were used to date the monolith from Johnny's Wood using an approach developed by Boyle et al. (2011). (1) The lead (Pb) pollution peak representing the period of lead mining between 1860-1865 at nearby Force Crag (Tyler 1990); (2) the re-introduction of Pinus sylvestris in the early 1900's in the lake District (Berry and Beard 1980); (3) The mid 1920's decline in elm populations because of disease (Harwood, Tomlinson et al. 2011); (4) The Pb pollution peak prior to the phasing out of alkyl-lead additive in fuel due to environmental legislation implemented in the 1970's. 
Three samples of Wistman's Wood mor humus were submitted for radiocarbon age determination by accelerator mass spectrometry (AMS). Dating mor humus material can be difficult due to the mobility of soluble organic acids (Scharpenseel and Becker-Heidmann 1992). However although previous studies had been successful with samples from Scotland (O'Sullivan 1973), Northern Ireland (Cruickshank and Cruickshank 1981) and Denmark (Iversen 1969), there appear not to have been any published studies in recent years. Dating material was selected in conjunction with scientists at the SUERC Radiocarbon Dating Facility in East Kilbride. The main concern was the effect of contemporary and recent root inclusion within the samples so all roots were picked out by hand from the samples prior to analysis.

Three thin sediment samples from Almeberget were submitted for AMS dating to Lund University and the peak values for $\mathrm{Pb}$ in the core were correlated with dated values from a nearby lake (Bindler, Rydberg et al. 2011). All radiocarbon dates were calibrated and plotted using CLAM (Blaauw 2010).

Results

Johnny's Wood, Lake District 


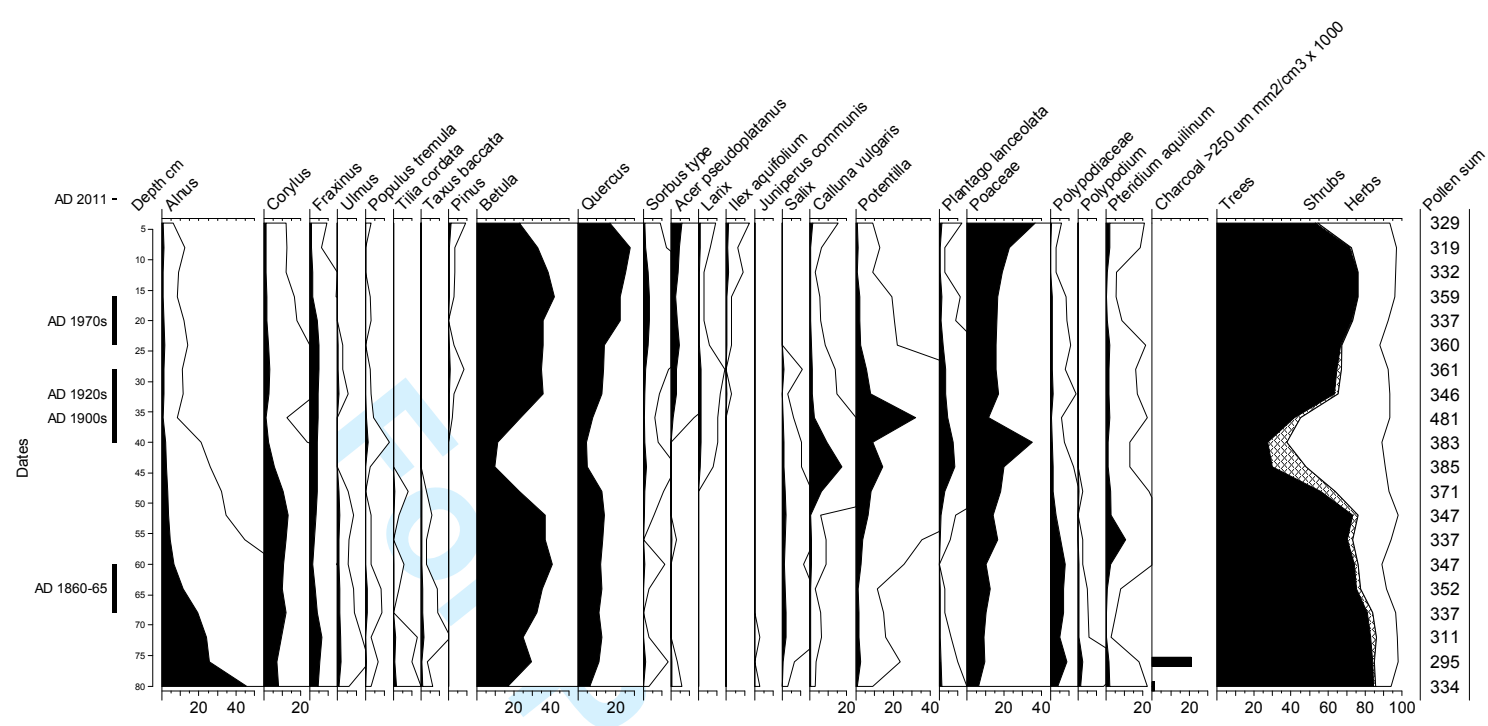

Fig. 1. Summary percentage pollen diagram from Johnny's Wood, UK small hollow.

The depth ranges in the core for the four chronological markers were found to be: (1) The first Pb pollution peak at $64 \mathrm{~cm}$ (lower limit $60 \mathrm{~cm}$ and upper limit $68 \mathrm{~cm}$ ); (2) The re-introduction of Pinus sylvestris was observed at $36 \mathrm{~cm}$ (lower limit $32 \mathrm{~cm}$ and upper limit $40 \mathrm{~cm}$ ); (3) The mid 1920's decline in elm at $32 \mathrm{~cm}$ (lower limit $28 \mathrm{~cm}$ and upper limit $36 \mathrm{~cm}$ ) and; (4) The second Pb pollution peak at $20 \mathrm{~cm}$ (lower limit $16 \mathrm{~cm}$ and upper limit $24 \mathrm{~cm}$ ). It can also be assumed the top of the core $(0 \mathrm{~cm})$ represents the coring year of 2011. The four chronological markers increase in age with depth in an approximately linear manner.

The major features of the pollen diagram of Birks (1993) have been reproduced in this study showing a forest clearance between $35-45 \mathrm{~cm}$ depth with peak values of Calluna vulgaris, Poaceae, Potentilla and Pteridium aquilinum and subsequent local disappearance of Tilia cordata, Taxus baccata and severe reduction in population size of Alnus glutinosa, Corylus avellana and Ulmus (Fig.1). Birks (1993) interpreted these dynamics as "corresponding to the time of the local Norse settlement at about $900 \mathrm{AD}$ " but he used no formal dating method in his study. Our chronology dates the 
1

2

3

4

5

6

7

8

9

10

11

12

13

14

15

16

17

18

19

20

21

22

23

24

25

26

27

28

29

30

31

32

33

34

35

36

37

38

39

40

41

42

43

44

45

46

47

48

49

50

51

52

53

54

55

56

57

58

59

60

clearance episode almost 1000 years later to the early 1900s (Fig.1). The new chronology receives further biostratigraphic support from the planting of Larix and Acer pseudoplatanus which chiefly occurred in the Lake District during the late 1800s and early 1900s, several centuries after the Viking Period. The current forest composition which is dominated by Quercus, Betula, Sorbus and Ilex has largely developed during the last 100 years and several other tree species have recently disappeared from the forest or become rare. Charcoal was only observed between 72 and $80 \mathrm{~cm}$ in depth dating from the early AD 1800s and is most likely associated with small-scale, pre-industrial production of charcoal.

Wistman's Wood, Dartmoor

Table 2. Radiocarbon dates for Wistman's Wood, U.K.

\begin{tabular}{|c|c|c|c|}
\hline $\begin{array}{c}\text { Publication } \\
\text { Code }\end{array}$ & $\begin{array}{c}\text { Depth } \\
(\mathrm{cm})\end{array}$ & $\begin{array}{c}\text { Conventional } \\
\text { Radiocarbon Age } \\
(\mathrm{yrs} B \mathrm{~B})\end{array}$ & $\begin{array}{c}\text { Calibrated Age } \\
\text { (years BP) }\end{array}$ \\
\hline SUERC-23850 & 21.1 & $106 \pm 37$ & $80 \pm 68$ \\
\hline SUERC-23851 & 31.7 & $1067 \pm 35$ & $971 \pm 43$ \\
\hline SUERC-23854 & 36.7 & $1208 \pm 35$ & $1122 \pm 66$ \\
\hline
\end{tabular}




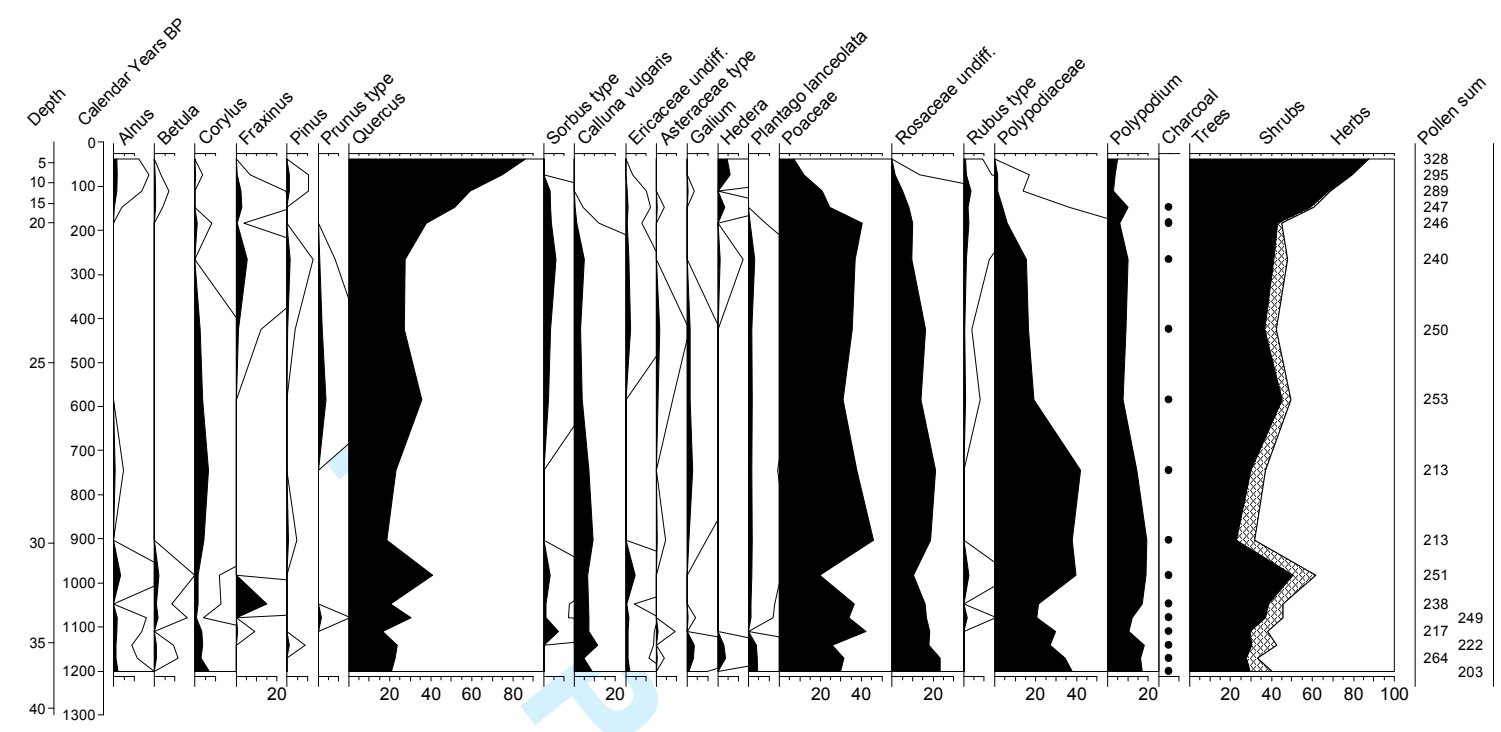

Fig.2 Summary percentage pollen diagram from Wistman's Wood, UK mor humus profile.

The radiocarbon dates showed that the record covered the last c.1200 years with the humus less compacted and decomposed in the upper sections of the core (Table 2). Arboreal pollen is dominated by Quercus, with some Corylus, Betula, Alnus, Fraxinus during the period 900-1200 years ago (Fig.2). Calluna vulgaris pollen is present suggesting open but relatively diverse woodland. Herbaceous species include Asteraceae type, Galium and Hypericum together with significant amounts of Poaceae and Rosaceae undiff. Plantago lanceolata and Polypodium are present in significant amounts throughout this time period and micro-charcoal is recorded in every sample, suggesting a woodland environment influenced by human activities, with fire used to improve grazing conditions for domestic animals.

Arboreal species diversity decreases between 900 and 170 years ago, with both Alnus and Betula not represented. Quercus continues to dominate the arboreal taxa, showing a gradual increase in percentage values. Corylus is present in the early section, however decreases towards the middle and is only present in minimal amounts afterwards. Pinus also makes an appearance towards the 
latter part of this time period and Sorbus type pollen percentages increase slightly during later years. Calluna vulgaris pollen is continuously present during this period. Poaceae levels reach their highest of the record at end of this time period, with levels remaining relatively consistent throughout, while Polypodium representation decreases throughout the period. Micro-charcoal is present in every sample and Wistman's Wood was heavily exploited during this period by burning and grazing. Historical records show that grazing by cattle, sheep and horses of the moorland has been intense for at least 700 years (Barkham 1978).

Quercus pollen dominates the time period during the last 170 years, with percentage values increasing gradually throughout from approximately $40 \%$ to $80 \%$, consistent with a long photographic record (Proctor, Spooner et al. 1980). Other arboreal taxa present are Alnus, Betula, Corylus, Fraxinus and Pinus, but levels never exceed 5\%. Calluna vulgaris is lost completely, along with many other herbaceous species. Hedera helix is present at its highest amounts of the record, with levels approaching $10 \%$. Poaceae decreases from previous maximum values, to its lowest value of the record, approximately $10 \%$. Micro-charcoal is present in only one sample at the start of the time period.

\section{Almeberget, Halland, Sweden}

Table 3. Radiocarbon dates for Almeberget Marsh, Sweden

\begin{tabular}{|c|c|c|c|}
\hline $\begin{array}{c}\text { Publication } \\
\text { Code }\end{array}$ & $\begin{array}{c}\text { Depth } \\
(\mathrm{cm})\end{array}$ & $\begin{array}{c}\text { Conventional } \\
\text { Radiocarbon Age } \\
(\mathrm{yrs} B \mathrm{P})\end{array}$ & $\begin{array}{c}\text { Calibrated Age } \\
\text { Range } \\
\text { (years BP) }\end{array}$ \\
\hline LuS-9662 & $47-48$ & $880 \pm 45$ & $726-902$ \\
\hline LuS-9663 & $79-80$ & $1520 \pm 50$ & $1348-1490$ \\
\hline LuS-9664 & $94-96$ & $1780 \pm 50$ & $1606-1806$ \\
\hline
\end{tabular}




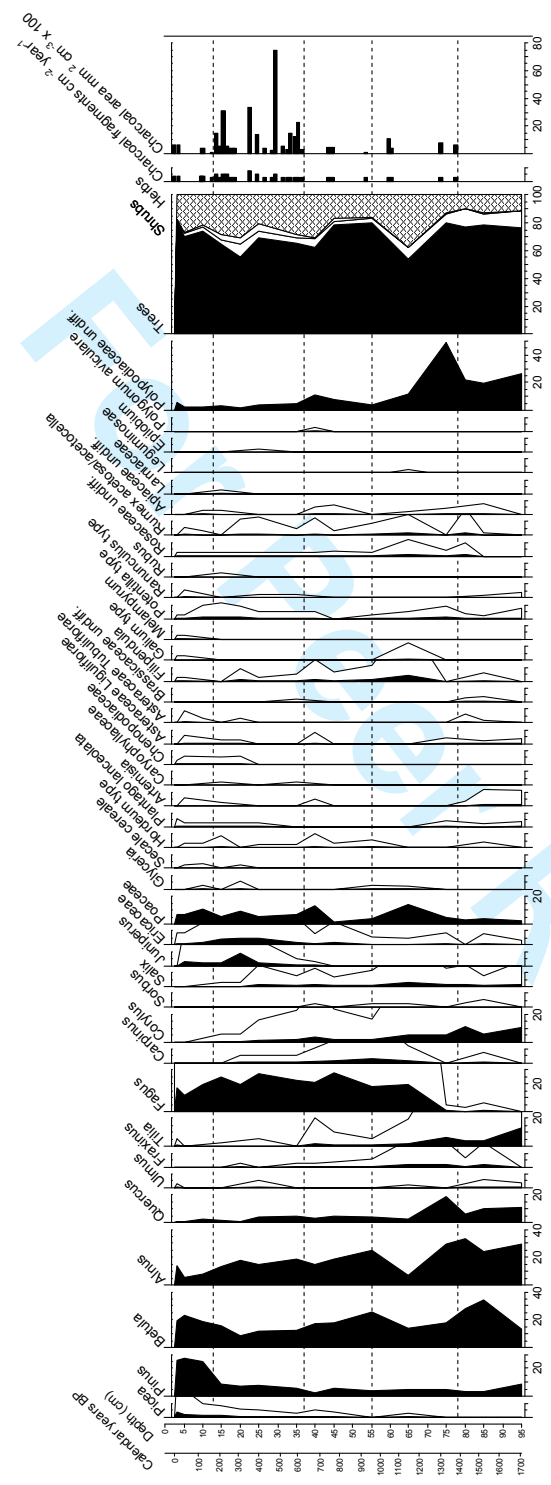

47

48

49

51

52

53

54

55

http://mc.manuscriptcentral.com/holocene 
Fig.3 Summary percentage pollen diagram from Almeberget Marsh, Sweden. Only charcoal fragments $>250 \mu$ were included in the analysis.

The radiocarbon dates showed that the Almeberget sediments covered the last 1800 years and the maximum $\mathrm{Pb}$ concentration was found at $12 \mathrm{~cm}$ depth corresponding to $150 \mathrm{BP}$ (Bindler, Rydberg et al. 2011)(Table 3). The pollen record shows a significant transformation in forest type from mixed deciduous forest comprising Tilia, Quercus, Alnus, Ulmus and Corylus with abundant Polypodiaceae in the understorey to a Fagus-dominated forest with evidence for frequent local burning between 600 and 200 years ago and consequent indicators of openings in the forest with occurrence of Poaceae, Ericaceae, Epilobium and recent successions involving Juniperus communis (Fig.3). The mixed deciduous forest that existed prior to Fagus expansion had previously dominated the region for 8000 years (Hannon, pers.comm.) and a case can be argued that this forest type forms a type of 'natural baseline' because its partial replacement by Fagus is usually linked with human activity in this part of Europe (Björkman and Karlsson 1999; Bradshaw and Lindbladh 2005). At Almeberget there is evidence for small-scale, local cultivation between 1780 and 1520 years ago comprising low pollen percentages of an assemblage of agricultural weeds including Plantago lanceolata, Artemisia, Asteraceae, Brassicaceae, Ranunculus, Rumex and Apiaceae, together with a single record of Hordeum-type pollen (Fig.3). There are a few undated clearance cairns within the present forest that possibly date from this period, but they may be considerably older (Fig.4). The local establishment of Fagus follows this anthropogenic disturbance, which is a sequence of events that has also been recognised in other parts of Halland (Björkman and Karlsson 1999) and elsewhere in southern Scandinavia (Odgaard 1994; Bradshaw and Lindbladh 2005; Lagerås 2007). Picea plantation and fire suppression have been features of the last c.100 years. Most Holocene fire in this part of southwest Sweden is associated with human activities (Bradshaw, Lindbladh et al. 2010). While there has been local forest continuity over parts of the area, both forest composition and disturbance regime have been modified by human activities during the last 1800 years. 


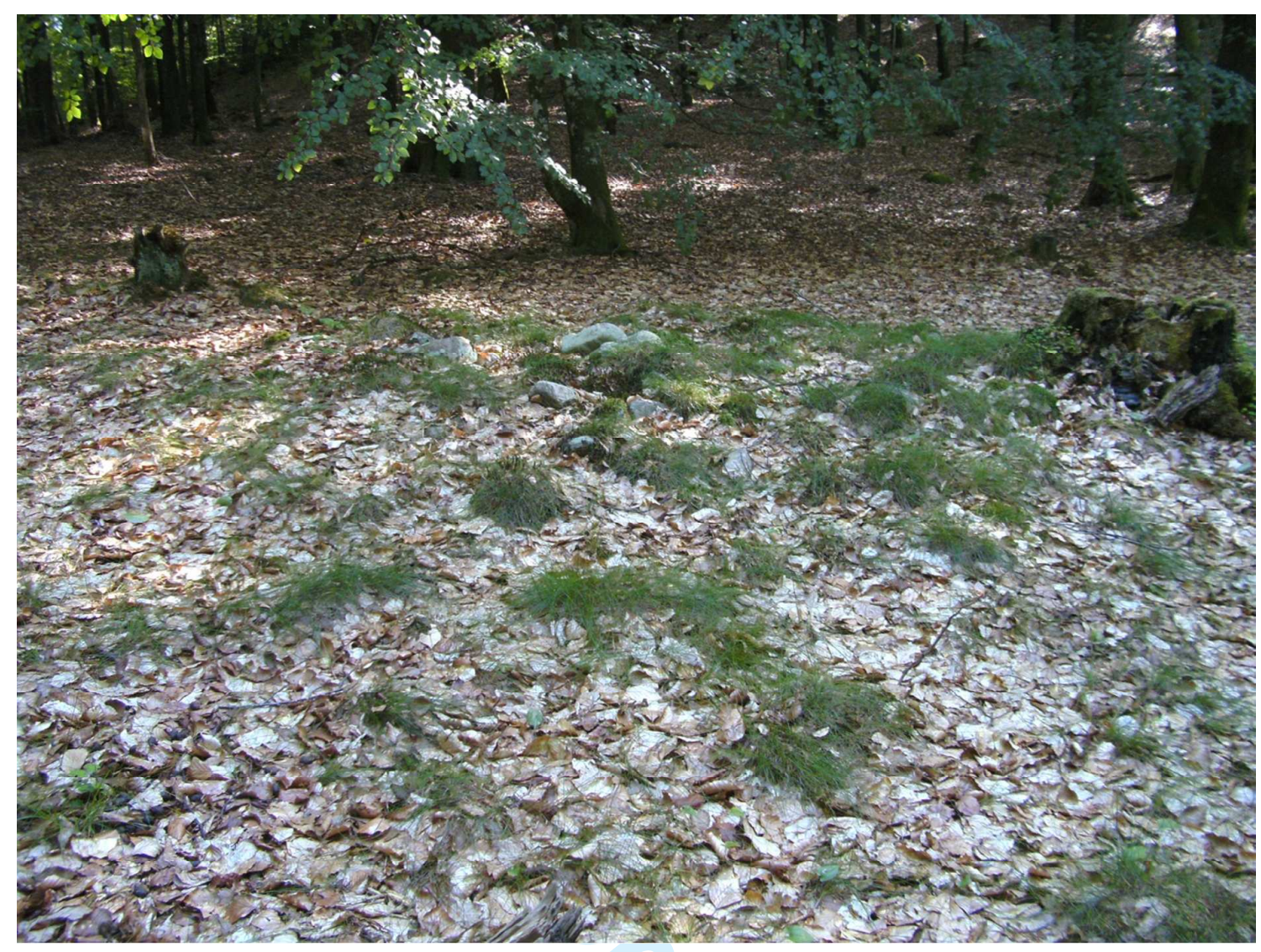

Fig.4 Ancient clearance cairn close to Almeberget Marsh, Sweden. Photo: Gina Hannon.

\section{Discussion}

All three of the sites investigated in this paper have been judged to be of high conservation interest and are parts of valued protected areas. Yet two of the sites are not primary forest, showing clear breaks in forest continuity less than 200 years ago and the third has experienced a major change in dominant forest type with a fluctuating and artificial fire disturbance regime that created openings in the forest canopy. In the British examples, long forest continuity and a close-to-nature disturbance regime were apparently not critical properties for the maintenance of important biological values. These findings fully support very similar observations made from four bryophyterich Quercus woodlands in Snowdonia, Wales, where pollen analysis showed significant forest disturbance during the last 300 years (Edwards 1986), and from Killarney National Park, Ireland (Mitchell 1988; Mitchell 1990; Mitchell 2013). Hannon, Niklasson et al. (2010) have described similar 
changes in forest dominants and fire regime from another Swedish biodiversity 'hotspot' where both Fagus and Picea established and expanded during the last 500 years following a series of continuous fires between c. $1000-500 \mathrm{BP}$ and comparable changes have been recorded from other small hollows in southern Sweden (Lindbladh, Bradshaw et al. 2000). All these sites are from local sites with high spatial resolution, but taken together they indicate consistent sequences of events. The hypothesis that the perceived conservation value is directly linked to long-term forest cover or the primary forest condition as defined by CBD is not upheld.

As in many other parts of Europe, much of the landscape surrounding these reserves shows a biome transformation within recent centuries largely as a result of human influence acting over long periods of time. Forests have been converted to heathland or moorland in the Lake District and on Dartmoor since at least the Late Bronze Age (Pennington 1981; Fyfe and Woodbridge 2012). In Halland, much native deciduous woodland has been converted into Picea plantation during the last 150 years (Fritz, Gustafsson et al. 2008; Lindbladh, Hultberg et al. 2011). Therefore the reserves under study were probably closer to a natural state than nearby habitat, despite their long histories of varied anthropogenic influence. Furthermore these reserves today are islands of diversity in rather homogeneous and species-poor landscapes that was probably not the case in the past. When forest reappeared at the UK sites following past breaks in continuity, there was almost certainly a larger reservoir of forest species available for recolonisation than is the case today. The reserves today have become isolated islands of diversity, as described by Segerström et al. (1994) for a boreal forest nature reserve in northern Sweden, and quite probably these reserves are now more sensitive to clearance and disturbance than in the past because of a lack of reservoir populations for recolonisation. Spracklen et al. (2013) found that native trees regenerated better on clear-felled conifer plantations in upland Britain when these sites were adjacent to mature native trees, so the matrix of surrounding vegetation is likely to be an important factor in how forest diversity recovers following disturbance. 
The species that confer diversity and conservation interest in these forest reserves today, are bryophytes, lichens, insects and fungi. The propagules of these organism groups are small and usually more easily dispersed than higher plants or mammals and might be expected to have good recolonisation properties. However Fritz et al. (2008) demonstrated that several red-listed lichens and bryophytes were more frequently found in Halland Fagus forests that had a continuity of longer than 350 years as shown on historical maps. Ellis (2012) reviewed lichen ecology and showed that few lichens are confined to single tree species and while some lichens are weak spore producers, the availability of suitable habitat, including old trees, was a critical factor in the local diversity of lichen assemblages. Indeed in Scandinavian boreal forests, high diversity of important lichen and fungal species has been associated with the frequency of natural forest disturbances rather than stand continuity (Ohlson, Söderström et al. 1997). In Halland, the older Fagus forests tend to have greater structural diversity than the surrounding uniform managed forest areas, so perhaps the long-term maintenance of structural diversity, particularly the continuity of old trees, is a more important factor for biodiversity value than just continuity of primary forest. Regular small-scale disturbance can generate this structural diversity. Heylen et al. (2005) found that fungi, lichens, mosses and ferns had greater diversity in young forests of mixed structure, than in structurally uniform old growth sites in temperate Belgian forest, while Verheyen et al. (2003) showed that forest age and distance from a seed source, rather than forest structure, was the most important factor for recolonisation of secondary woodlands for herbaceous plants, also in Belgium.

The hypothesis that perceived conservation value in the study sites is directly linked to the primary forest condition is rejected for the three sites under investigation and this provides encouragement for effective restoration of forest habitat. Sites of high conservation value have developed in both the UK and southern Sweden in areas with evidence of former human impact, where local sources of diversity have survived. Relaxation of that impact for less than 200 years, which is shorter than the life-spans of the dominant trees, has considerably increased their value for conservation. Birks (1993) commented that Johnny's Wood had developed a diverse bryophyte flora a mere 1000 years 
after a break in forest continuity, yet as we have demonstrated that break in continuity was almost certainly just 100 years ago. Temperate forest ecosystems are more resilient and dynamic than was previously thought to be the case at least for species that are well dispersed and retain suitable reservoirs for recolonisation in the region. Trees and other higher plants are probably the group of species that have the weakest recolonisation potential and for these species, continuity of site occupation is more important. Palaeoecological studies of sites with high conservation value have increased understanding of forest dynamics and likely controls of diversity (Mitchell 2013). Pollen studies with high spatial resolution demonstrate that simple temporal concepts like 'natural baselines' and the continuity of forest cover underestimate the complexity of the past. Long forest continuity may be of importance for the local survival of higher plants, but for the insects, fungi, lichens and bryophytes that are so valued in European temperate and boreal forests, habitat diversity maintained by dynamic processes would appear to be of greater significance.

\section{Acknowledgements}

We thank Hallands Länsstyrelsen, EU FP6 EVOLTREE Network of Excellence, the Swedish Foundation for International Cooperation in Research and Higher Education through project DYNAMITE, SUERC dating facility and John Birks, for good advice and money.

\section{References}

Barkham, J. P. (1978). "Pedunculate Oak woodland in a severe environment: Black Tor Copse, Dartmoor." Journal of Ecology 66(3): 707-740.

Berglund, B. E. (1986). Handbook of Holocene palaeoecology and palaeohydrology. Chichester, United Kingdom, John Wiley \& Sons.

Berry, G. and G. Beard (1980). The Lake District: a century of conservation, J. Bartholomew.

Bindler, R., J. Rydberg, et al. (2011). "Establishing natural sediment reference conditions for metals and the legacy of long-range and local pollution on lakes in Europe." Journal of Paleolimnology 45: 519-531. 
Birks, H. J. B. (1993). "Quaternary palaeoecology and vegetation science - current contributions and possible future developments." Review of Palaeobotany and Palynology 79: 153-177.

Birks, H. J. B. (2012). "Ecological palaeoecology and conservation biology: controversies, challenges, and compromises." International Journal of Biodiversity Science, Ecosystem Services \& Management 8(4): 292-304.

Björkman, L. and M. Karlsson (1999). "Bokskogens historia i sydvästra Sverige - exempel från paleoekologiska undersökningar av bokskogslokaler i Halland." Svensk Botanisk Tidskrift 93: 107-122.

Blaauw, M. (2010). "Methods and code for 'classical' age-modelling of radiocarbon sequences." Quaternary Geochronology 5(5): 512-518.

Boyle, J. F., M.-J. Gaillard, et al. (2011). "Modelling prehistoric land use and carbon budgets: a critical review." Holocene 17: 715-722.

Bradshaw, R. H. W. (2013). Stand-Scale Palynology. The Encyclopedia of Quaternary Science. S. A. Elias. Amsterdam, Elsevier. 3: 846-853.

Bradshaw, R. H. W. and M. Lindbladh (2005). "Regional spread and stand-scale establishment of Fagus sylvatica and Picea abies in Scandinavia." Ecology 86(7): 1679-1686.

Bradshaw, R. H. W., M. Lindbladh, et al. (2010). "The role of fire in southern Scandinavian forests during the late Holocene." International Journal of Wildland Fire 19: 1040-1049.

Coppins, B. J. and A. M. Coppins (2005). "Lichens - the biodiversity value of western woodlands." Botanical Journal of Scotland 57(1-2): 141-153.

Cruickshank, J. G. and M. M. Cruickshank (1981). "The development of humus-iron podsol profiles, linked by radiocarbon dating and pollen analysis to vegetation history." Oikos 36: 238-253.

Dambrine, E., J.-L. Dupouey, et al. (2007). "Present forest biodiversity patterns in France related to former Roman agriculture." Ecology 88(6): 1430-1439.

Edwards, M. E. (1986). "Disturbance histories of four Snowdonian woodlands and their relation to Atlantic bryophyte distributions." Biological Conservation 37: 301-320.

Ellis, C. J. (2012). "Lichen epiphyte diversity: A species, community and trait-based review." Perspectives in Plant Ecology, Evolution and Systematics 14: 131-152.

Fritz, O., L. Gustafsson, et al. (2008). "Does forest continuity matter in conservation? - A study of epiphytic lichens and bryophytes in beech forests of southern Sweden." Biological Conservation 141: 655-668.

Fyfe, R. M. and J. Woodbridge (2012). "Differences in time and space in vegetation patterning: analysis of pollen data from Dartmoor, UK." Landscape Ecology 27: 745-760.

Goldberg, E., K. Kirby, et al. (2007). "The ancient woodland concept as a practical conservation tool in Great Britain." Journal for Nature Conservation 15: 109-119.

Hannon, G. E., M. Niklasson, et al. (2010). "How long has the 'hotspot' been 'hot'? Past stand-scale structures at Siggaboda nature reserve in southern Sweden." Biodiversity and Conservation 19: 2167-2187.

Harwood, T. D., I. Tomlinson, et al. (2011). "Dutch elm disease revisited: past, present and future management in Great Britain." Plant Pathology 60: 545-555.

Heylen, O., M. Hermy, et al. (2005). "Determinants of cryptogamic epiphyte diversity in a river valley (Flanders)." Biological Conservation 126: 371-382.

Iversen, J. (1969). "Retrogressive development of a forest ecosystem demonstrated by pollen diagrams from fossil mor." Oikos supplement 12: 35-49.

Lagerås, P. (2007). The ecology of expansion and abandonment: Medieval and Post-medieval agriculture and settlement in a landscape perspective, Riksantikvarieambetets forlag.

Lindbladh, M., R. H. W. Bradshaw, et al. (2000). "Patterns and process in south Swedish forests during the last 3000 years, sensed at stand and regional scales." Journal of Ecology 88: 113128.

Lindbladh, M., S. Fraver, et al. (2013). "Past forest composition, structures and processes - How paleoecology can contribute to forest conservation." Biological Conservation 168: 116-127. 
Lindbladh, M., T. Hultberg, et al. (2011). "Halland's forests during the last 300 years: a review of Malmström (1939)." Scandinavian Journal of Forest Research 26: 81-90.

Lindbladh, M., M. Niklasson, et al. (2008). "Close anthropogenic control of Fagus sylvatica establishment and expansion in a Swedish protected landscape - implications for forest history and conservation." Journal of Biogeography 35: 682-697.

Mitchell, F. J. G. (1988). "The vegetational history of the Killarney Oakwoods, S.W.Ireland: evidence from fine spatial resolution pollen analysis." Journal of Ecology 76: 415-436.

Mitchell, F. J. G. (1990). "The impact of grazing and human disturbance on the dynamics of woodland in S.W. Ireland." Journal of Vegetation Science 1: 245-254.

Mitchell, F. J. G. (2013). "Long-term changes and drivers of biodiversity in Atlantic oakwoods." Forest Ecology and Management 307: 1-6.

Mooney, S. and M. Black (2003). "A simple and fast method for calculating the area of macroscopic charcoal isolated from sediments." Quaternary Australasia 21(1): 18-21.

Moore, P. D., J. A. Webb, et al. (1991). Pollen analysis. London, Blackwell.

O'Sullivan, P. (1973). "Pollen analysis of mor humus layers from a native Scots pine ecosystem, interpreted with surface samples." Oikos 24: 259-272.

Odgaard, B. V. (1994). Holocene vegetation history of northern West Jutland, Denmark. Copenhagen.

Ohlson, M., L. Söderström, et al. (1997). "Habitat qualities versus long-term continuity as determinants of biodiversity in boreal old-growth swamp forests." Biological Conservation 81: 221-231.

Pennington, W. (1981). "Records of a lake's life in time: the sediments." Hydrobiologia 79: 197-219.

Prentice, I. C. (1985). "Pollen Representation, Source Area, and Basin Size - toward a Unified Theory of Pollen Analysis." Quaternary Research 23(1): 76-86.

Proctor, M. C. F., G. M. Spooner, et al. (1980). "Changes in Wistman's Wood, Dartmoor: photographic and other evidence." Transactions of the Devonshire Association for the Advancement of Science, Literature \& the Arts 112: 43-80.

Ratcliffe, D. A., Ed. (1977). A nature conservation review. Cambridge, Cambridge University Press.

Scharpenseel, H. W. and P. Becker-Heidmann (1992). "Twenty-five years of radiocarbon dating soils: paradigm of erring and learning." Radiocarbon 34(3): 541-549.

Segerström, U., R. H. W. Bradshaw, et al. (1994). "Disturbance history of a swamp forest refuge in northern Sweden." Biological Conservation 68: 189-196.

Spracklen, B. D., J. V. Lane, et al. (2013). "Regeneration of native broadleaved species on clearfelled conifer plantations in upland Britain." Forest Ecology and Management 310: 204-212.

Sugita, S., T. Parshall, et al. (2010). "Testing the Landscape Reconstruction Algorithm for spatially explicit reconstruction of vegetation in northern Michigan and Wisconsin." Quaternary Research 74(2): 289-300.

Tyler, I. (1990). Force Crag: the history of a lakeland mine, Red Earth.

Verheyen, K., G. R. Guntenspergen, et al. (2003). "An integrated analysis of the effects of past land use on forest herb colonization at the landscape scale." Journal of Ecology 91: 731-742.

Waltert, M., K. S. Bobo, et al. (2011). "Assessing conservation values: Biodiversity and endemicity in tropical land use systems." PLoS ONE 6(1): e16238.

Wardenaar, E. P. C. (1987). "A new tool for cutting peat profiles." Canadian Journal of Botany 65: 1772-1773.

Willis, K. J., R. M. Bailey, et al. (2010). "Biodiversity baselines, thresholds and resilience: testing predictions and assumptions using palaeoecological data." Trends in ecology and Evolution 25: 583-591.

Willis, K. J. and H. J. B. Birks (2006). "What Is Natural? The Need for a Long-Term Perspective in Biodiversity Conservation." Science 314: 1261-1265.

Willis, K. J., L. Gillson, et al. (2004). "How "Virgin" Is Virgin Rainforest?" Science 304: 402-403. 
1

2

3

4

5

6

7

8

9

10

11

12

13

14

15

16

17

18

19

20

21

22

23

24

25

26

27

28

29

30

34

35

36

37

38

39

40

41

42

43

44

45

46

47

48

49

50

51

52

53

54

55

56

57

58

59

60

http://mc.manuscriptcentral.com/holocene 


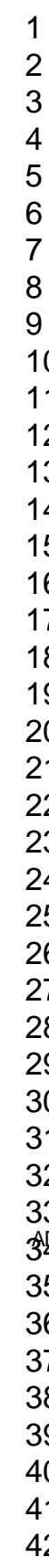




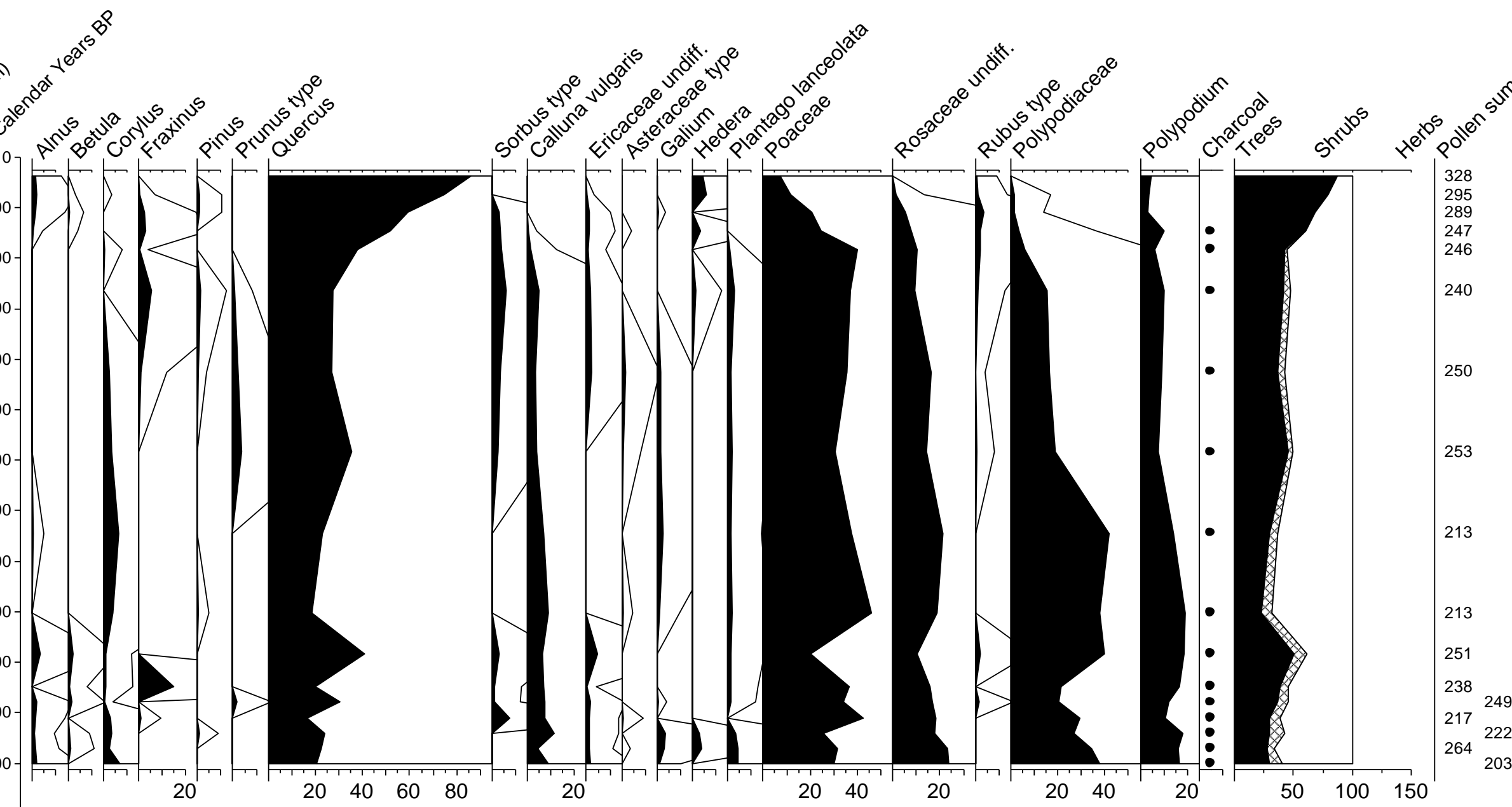




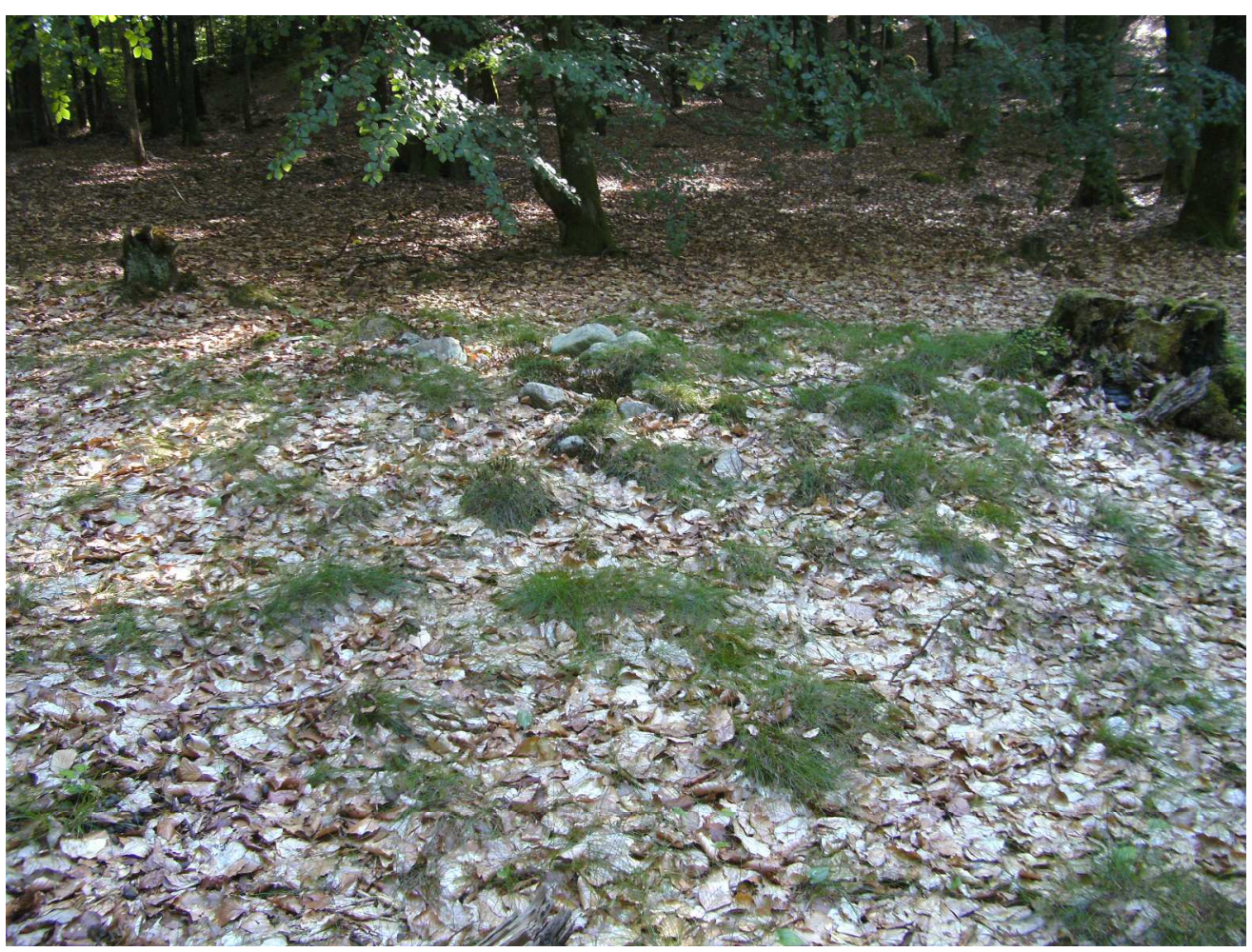

$460 \times 345 \mathrm{~mm}(180 \times 180 \mathrm{DPI})$ 